\title{
SHOULD COURTS DEDUCT NONLEGAL SANCTIONS FROM DAMAGES?
}

\author{
ROBERT COOTER and ARIEL PORAT*
}

\begin{abstract}
When legal and social norms regulate the same behavior, an act can trigger both legal and nonlegal sanctions. Should courts deduct the nonlegal sanction suffered by the wrongdoer from damages owed to the victim? We provide the answer for a legal system that seeks to minimize social costs. Nonlegal sanctions typically harm the wrongdoer and benefit other people. In principle, courts should avoid overdeterring wrongdoers by deducting the benefit of the nonlegal sanction from compensatory damages. In practice, instead of deducting the benefit of the nonlegal sanction to other people, courts should deduct the burden on the wrongdoer. Deducting the burden of the nonlegal sanction from compensatory damages typically improves the incentives of wrongdoers and victims. We make practical suggestions for courts to implement our proposal that would significantly reduce damages in torts and contracts.
\end{abstract}

\section{S} violates a social norm, whom we call the "wrongdoer," may suffer a nonlegal sanction. The person harmed by the wrong, whom we call the "victim," may sue the wrongdoer for damages. The suit is usually in torts or contracts, but it can occur in any body of liability law in which social and legal norms align. Thus, the total sanction suffered by the wrongdoer equals the nonlegal sanction plus damages. This situation poses a question that apparently remains unexplored in legal theory. Courts typically try to set damages at the level required to compensate the victim. Should courts deduct the nonlegal sanction suffered by the wrongdoer from compensary damages owed to the victim? We provide the answer for a legal system that seeks to minimize social costs.

* Herman F. Selvin Professor of Law and Director of the John Olin Program in Law and Economics, University of California at Berkeley; and Professor of Law and Director of the Cegla Institute, Tel Aviv University, respectively. We received helpful comments from Melvin Eisenberg; Omri BenShahar; Jesse Fried; Chris Kutz; Barak Medina; Michelle White; the law faculty seminar of Haifa University; the Siena Conference on Law and Economics at Pontignano (June 2000); the law and economics workshops at the University of Hamburg, the University of California at Berkeley, the University of Michigan, and the University of Tel Aviv; and an anonymous referee.

1 The growing literature on social norms has largely overlooked the interaction between damages and nonlegal sanctions. For an exception that considers this interaction, see Lisa Bernstein, Private Commercial Law in the Cotton Industry: Value Creation through Rules, Norms, and Institutions, 99 Mich. L. Rev. (forthcoming 2001). For a discussion of the differences in the incentives of legal and nonlegal sanctions for breach of contract, see David Charny, Nonlegal Sanctions in Commercial 
When legal and social norms align, the wrong committed by the defendant harms the plaintiff and triggers nonlegal sanctions that harm the wrongdoer. Besides harming the wrongdoer, nonlegal sanctions typically benefit other people by informing, protecting, or transferring business to them. To illustrate, damaging the wrongdoer's reputation alerts potential victims to avoid him, and boycotting a wrongdoer may transfer business to his competitors; these nonlegal sanctions protect potential victims by deterring other wrongdoers.

In simple economic models of liability, incentives are best when the damages equal the net social costs of the act that triggered liability. This is true in almost all models of strict liability rules and most models of negligence rules. By focusing on the most important elements of social costs, we reduce a long list to the sum of these three elements: (1) plaintiff's harm from the wrong, plus (2) defendant's harm from the nonlegal sanctions, minus (3) other peoples' benefit from the nonlegal sanctions. This paper considers in detail whether wrongdoers internalize each of the three elements. Now we summarize the conclusions.

Liability for compensatory damages ideally makes the wrongdoer internalize the plaintiff's harm. Consequently, liability law ideally causes the internalization of the first element. Turning to the second element, the wrongdoer inevitably bears the harm that he suffers from the nonlegal sanctions. Consequently, the nature of the nonlegal sanction causes the wrongdoer to internalize the second element. The third element, however, creates a problem for wrongdoers' incentives. The wrongdoer typically externalizes the benefits to other people caused by bringing the nonlegal sanctions on himself. Externalization of the third element overdeters unintentional wrongdoing.

To avoid overdeterrence, the state could subsidize wrongdoers. A more practical alternative is for courts to reduce the wrongdoer's liability. We will argue that courts should award compensatory damages minus the benefits of the nonlegal sanction. We call this damage measure "ideal net damages" because damages computed in this way are ideal for wrongdoers' incentives. Courts should award ideal net damages in the typical case in which nonlegal sanctions benefit other people. Courts should award compensatory damages only in the atypical case in which the nonlegal sanctions are a deadweight loss that does not benefit anyone.

After analyzing wrongdoers' incentives, we next consider victims' incentives. Victims can typically reduce the expected harm from accidents, breach of contract, and nuisances. ${ }^{2}$ Compensatory damages typically erode victims' incentives to reduce expected harm. Unlike damages, however, nonlegal sanc-

Relationships, 104 Harv. L. Rev. 373, 400-403 (1990). For the relationship between criminal punishment and nonlegal sanctions, see Dan M. Kahan \& Eric A. Posner, Shaming White-Collar Criminals: A Proposal for Reform of the Federal Sentencing Guidelines, 42 J. Law \& Econ. 365 (1999)

${ }^{2}$ Robert Cooter, Unity in Torts, Contracts and Property: The Model of Precaution, 73 Cal. L. Rev. 1 (1985). 
tions typically do not compensate victims. ${ }^{3}$ By substituting nonlegal sanctions for damages, courts can improve victims' incentives to avoid harm. If courts must award damages to victims, then a reduction in their amount typically improves victims' incentives. Consequently, deducting the benefit of the nonlegal sanction from compensatory damages typically improves victims' incentives.

Having made these theoretical arguments about injurers' and victims' incentives, we turn to a practical issue. Courts that attempt to minimize social costs by awarding ideal net damages will sometimes have difficulty determining the extent of the benefits of the nonlegal sanction. We will argue that instead of deducting benefits from the compensatory damages owed to the victim, practical considerations commend courts to deduct the burden of the nonlegal sanction on the wrongdoer. We call this damage measure "practical net damages." Implementing this proposal, which makes modest demands on courts, would significantly reduce the damages awarded in many cases.

In principle, social efficiency in contracts or torts requires eliminating all externalities by adjusting damages for third-party effects. The difference between nonlegal sanctions and other externalities is practical rather than theoretical. Third-party effects in most cases are small, are unmeasurable, or have benefits and costs that offset each other. In addition, third-party effects are episodic. We will show, however, that the third-party effects of nonlegal sanctions are large, measurable, not offsetting, and endemic. For these reasons, courts should deduct the burden of nonlegal sanctions from damages, even though courts should not attempt to deduct third-party effects in most other cases.

The preceding analysis assumes that courts do not influence nonlegal sanctions, except possibly by announcing liability. Next we assume that courts can influence the form and size of nonlegal sanctions. We conclude that courts should try to substitute sanctions that create or transfer value for sanctions that destroy value. We also conclude that, under certain conditions, courts should substitute nonlegal sanctions for legal sanctions to improve the incentives of victims.

A mathematical appendix proves our general propositions.

\section{Wrongdoers' INCENTIVES WhEN NONLEGAL Sanctions Are Deadweight Losses}

We begin with some examples in which nonlegal sanctions are deadweight losses.

Example 1. A man who owns a small company flirts with a female employee. He mistakes her politeness for encouragement and, consequently,

\footnotetext{
${ }^{3}$ See Ariel Porat, Enforcing Contracts in Dysfunctional Legal Systems: The Close Relationship between Public and Private Orders, 98 Mich. L. Rev. 2459 (2000).
} 
acts unreasonably. In law, his unreasonable act is the tort of sexual harassment, but not a crime. As news of the event spreads, the owner's friends and associates become angry with him. The owner suffers a loss of reputation that he values at $\$ 25$. The owner's loss of reputation does not benefit anyone. The employee sues and the court finds that damages of $\$ 100$ will perfectly compensate the victim. Should the court award damages of $\$ 100$ or $\$ 75$ ?

Example 2. A company aggressively interprets a contract with a supplier and eventually breaches. When the supplier sues, the court finds that damages of $\$ 100$ will perfectly compensate the victim for breach. Although consumers who buy from the company are not at risk, the news of the court's finding makes some of them angry, and they boycott the company, which causes it to lose $\$ 25$ in profits. The market is so competitive that the boycott does not measurably harm consumers or benefit other sellers. ${ }^{4}$ Should the court award damages of $\$ 100$ or $\$ 75$ ?

If the law's goal is to compensate victims, then damages should equal $\$ 100$ in both examples. Alternatively, if the law's goal is to deter wrongdoers, then damages of $\$ 100$ deter more than damages of $\$ 75$. The economic analysis of private law, however, typically regards compensating victims or deterring wrongdoers as instrumental goals, behind which lies the ultimate goal of minimizing social costs. To minimize social costs, the wrongdoer should typically internalize the harm that he caused. In example 1, the owner caused $\$ 100$ of harm to the employee and $\$ 25$ of harm to himself from loss of reputation. In example 2, the company caused $\$ 100$ of harm to the supplier and $\$ 25$ of harm to itself from the boycott. By setting damages equal to $\$ 100$ in both cases, the wrongdoer will face a total sanction of $\$ 125$, which equals the total harm that he caused. Consequently, efficient deterrence requires the court to award perfectly compensatory damages in both cases, which equal $\$ 100$.

Now we will formulate the conclusion of examples 1 and 2 more abstractly. Over the years, the economic analysis of law has developed simplified models of torts and contracts. Standard assumptions for beginning an analysis include risk neutrality, zero litigation costs, no enforcement errors, one-shot transactions between the parties, and no "contracting around" the legal rule of liability. (It is relatively easy to determine whether a mathematical model makes a particular assumption, and it is relatively hard to think of all the assumptions that a mathematical model makes.) We will also assume that potential injurers and victims have the necessary information about damages and nonlegal sanctions to respond to them. Thus, we assume that the employer in example 1 who takes a risk and loses when flirting makes no mistake

\footnotetext{
${ }^{4}$ We have these specific assumptions in mind: consumers can shift costlessly to other sellers who continue earning zero profits, but the wrongdoer suffers a loss of reputation that raises its selling costs.
} 
about foreseeing future sanctions. Under assumptions such as these, equating the wrongdoer's total sanction with the victim's loss internalizes the harm caused by the wrongdoer, so the wrongdoer has incentives to minimize social costs.

Two assumptions are especially significant in examples 1 and 2 . First, we assume that the court sets damages but does not influence the nonlegal sanction. Second, in example 1 we assume that loss of reputation harms the owner without affecting anyone else. Shunning, shaming, criticizing, or disesteeming always harms someone and sometimes does not affect anyone else very much. For purposes of analysis, we assume in example 1 that no one else is affected at all. Similarly, in example 2 we assume that the boycott harms the defendant without affecting anyone else. In both examples, the nonlegal sanction destroys value rather than transferring or creating it.

Later we relax these assumptions, but now we can formulate our general conclusion from these two examples.

Proposition 1. Assume that nonlegal sanctions are a deadweight loss. Under standard assumptions, the wrongdoer has efficient incentives to avoid causing harm when damages perfectly compensate the victim.

According to Proposition 1, the goal of compensating victims aligns with the goal of deterring wrongdoers when the nonlegal sanction is a deadweight loss. The next section changes this assumption and brings these goals into conflict.

\section{Wrongdoers' InCEnTIVES When Nonlegal Sanctions Transfer or Create Value}

We now consider the possibility that wrongdoing benefits some people other than the wrongdoer, especially by triggering a nonlegal sanction. In principle, every kind of benefit or cost is relevant when minimizing net social costs. In practice, courts may restrict consideration to the most important elements, as when they apply the doctrine of "proximate cause" to remove remote harms from damages. Without empirical research, no one can say in advance whether to include or exclude a particular element of cost from the court's inquiry. To keep the analysis manageable, we make our best guess for the typical case and reduce a long list of benefits and costs caused by nonlegal sanctions to three benefits, which we illustrate by modifying our examples. First, the nonlegal sanction may convey information about the wrongdoer that enables potential victims to escape injury. To illustrate, the owner's loss of reputation in example 1 may alert potential victims of sexual harassment to avoid him. In this example, conveying the information that the wrongdoer violated the norm is the nonlegal sanction (loss of reputation). Similarly, the news that the company in example 2 aggressively interpreted a contract and breached it may enable other suppliers to avoid becoming 
victims. In this example, conveying the information that the wrongdoer violated the norm causes a nonlegal sanction (boycott).

Second, the nonlegal sanction may benefit competitors of the wrongdoer. To illustrate, with a small change in assumptions, the consumer boycott in example 2 that harms the defendant might benefit a competitor. Similarly, if the owner in example 1 competes with others for social status, then decreasing his social status by shunning, shaming, criticizing, or disesteeming may increase other peoples' social status. In general, nonlegal sanctions often convey advantages on the wrongdoer's economic and social competitors.

Third, the imposition of a nonlegal sanction in a particular case may deter the wrongdoer or other potential wrongdoers from causing future injuries. Potential victims of sexual harassment in example 1 may benefit because the owner's loss of reputation deters other people from committing sexual harassment, and potential suppliers of the company in example 2 may benefit because the boycott deters other companies from cheating on contracts.

Sanctions deter in two different ways. A norm is sometimes defined as an obligation backed by a sanction. A perfectly informed decision maker knows the probability and magnitude of the sanction. When a general practice determines the expected sanction faced by a wrongdoer, the news that a particular wrongdoer has been sanctioned usually confirms the general practice. Confirming a general practice modestly increases its credibility, so deterrence increases modestly. In general, if potential wrongdoers believe that wrongdoing will be sanctioned as part of a general practice, then a particular person who brings a sanction on himself by doing wrong contributes modestly to deterring others.

In reality, however, people have imperfect information about general practices, and nonlegal sanctions may be more personal than general. Given these facts, publicizing someone's punishment, especially someone who is well known, can significantly change beliefs about the probability and magnitude of a sanction. Similarly, many psychological studies show that people especially respond to risks that materialize in concrete cases ("availability heuristic"). Publicizing someone's punishment can raise its salience in the minds of potential wrongdoers. For these reasons, nonlegal sanctions applied to a particular person, without any change in general practices, can significantly deter wrongdoing. In general, the deterrence effect of the nonlegal sanction that a wrongdoer brings on himself, which may be modest or significant, counts as a benefit caused by his wrongdoing. ${ }^{5}$

We distinguished three types of benefit that can result when wrongdoing triggers a nonlegal sanction: transmitting information to potential victims, creating an advantage for the wrongdoer's competitors, and deterring future wrongdoing. These benefits are "external" in the sense that they accrue to

\footnotetext{
${ }^{s}$ Note that a nonlegal sanction could cause overdeterrence, which would count as a cost rather than a benefit.
} 
people other than the wrongdoer. To illustrate each type, we will modify the preceding examples.

Example 3. The man who owns a small company flirts with a female employee. He mistakes her politeness for encouragement and, consequently, acts unreasonably. In law his unreasonable act is the tort of sexual harassment, but not a crime. As news of the event spreads, the owner suffers a loss of reputation that he values at $\$ 25$. The owner's loss of reputation enables potential victims of his future misbehavior to avoid other uncompensated harms worth $\$ 40$. The employee sues, and the court finds that damages of $\$ 100$ will perfectly compensate the victim. Should the court award damages of $\$ 100, \$ 75$, or $\$ 60$ ?

To minimize social costs, the wrongdoer should typically internalize the net costs that he imposed on others. In example 3 , the wrongdoer caused harm of $\$ 100$ to the employee, and the nonlegal sanction that he brought on himself caused a loss of $\$ 25$ to himself, for a total cost of $\$ 125$. However, the nonlegal sanction caused a benefit of $\$ 40$ to others, so the net cost of his wrongdoing equals $\$ 85$. Efficient incentives require the sum of the nonlegal and legal sanctions to equal $\$ 85$. Since the wrongdoer suffers a nonlegal sanction of $\$ 25$, the costs that remain externalized after the nonlegal sanction equal $\$ 60$. Consequently, efficient incentives for the wrongdoer require the court to award damages of $\$ 60$.

To arrive at damages of $\$ 60$ by a shorter route, apply the general principle that efficient deterrence requires the court to set damages equal to the victim's harm $(\$ 100)$ minus the benefit to others $(\$ 40)$. By setting damages equal to $\$ 60$, the court will cause the wrongdoer to internalize the external cost of his wrongdoing, whereas setting damages equal to $\$ 75$ or $\$ 100$ will overdeter.

Setting damages above $\$ 60$ will overdeter potential injurers. In this case, overdeterrence implies excessive precaution when flirting. The risk assumed when flirting with someone, which is an important social activity that presumably benefits the people who practice it, should not be increased above the level that minimizes social costs.

Having illustrated how nonlegal sanctions convey beneficial information, we modify example 2 to illustrate how nonlegal sanctions can benefit competitors of the wrongdoer.

Example 4. A company aggressively interprets a contract with a supplier and eventually breaches. When the supplier sues, the court finds that damages of $\$ 100$ will perfectly compensate the victim for breach. Although consumers who buy from the company are not at risk, the news of the court's finding makes some of them angry, and they boycott the company, which causes it to lose $\$ 25$ in profits and its competitors to gain $\$ 25$ in profits. Should the court award damages of $\$ 100$ or $\$ 75$ ?

To find the answer, apply the general principle that efficient deterrence 
requires the court to set damages equal to the victim's harm $(\$ 100)$ minus the benefit to others $(\$ 25) .{ }^{6}$ Thus, the court should ideally award net damages, which equal $\$ 75$. Awarding damages of $\$ 100$ rather than $\$ 75$ would overdeter by prompting excessive precaution in contracts.

Example 3 illustrates how nonlegal sanctions convey beneficial information, and example 4 illustrates how nonlegal sanctions transfer value to competitors. Next we modify example 4 to illustrate how nonlegal sanctions deter.

Example 5. A company aggressively interprets a contract with a supplier and eventually breaches. When the supplier sues, the court finds that damages of $\$ 100$ will perfectly compensate the victim for breach. Although consumers who buy from the company are not at risk, the news of the court's finding makes some of them angry, and they boycott the company, which causes it to lose $\$ 25$ in profits and its competitors gain $\$ 25$ in profits. That fact that many consumers boycott sharp dealers has faded from the minds of some industry executives. Vivid reports of the boycott revive the memory and deter some executives from sharp dealing. If they had dealt sharply, they would have gained $\$ 5$ and imposed a cost of $\$ 20$ on their victims, for a net social loss of $\$ 15$. Should the court award damages of $\$ 100, \$ 75, \$ 60$, or some other number?

Let us apply the formula "damages equal victim's harm minus net benefits of the nonlegal sanction" to example 5. Thus, the court should deduct the value of the transfer $(\$ 25)$ and deterrence $(\$ 15)$ caused by the nonlegal sanction from the harm of $\$ 100$ suffered by the plaintiff, thus yielding damages of $\$ 60$.

Here is a longer explanation of the calculation. In example 5, the defendant caused harm of $\$ 100$ to the plaintiff, provoked a boycott that transferred $\$ 25$ to the defendant's competitors, and deterred wrongdoing whose net social cost is $\$ 15$. Thus, the net harm caused by the defendant's wrongdoing equals $\$ 85$. Efficient incentives require the sum of the nonlegal and legal sanctions to equal $\$ 85$. The nonlegal sanction (boycott) costs the company $\$ 25$, so damages should equal $\$ 60$. (Notice that, contrary to the usual multiplier models, imperfect compensation of future victims by courts lowers the damages owed by the defendant in this case. $)^{7}$

\footnotetext{
${ }^{6}$ Here is a more complete calculation that reaches the same conclusion. In example 4, the wrongdoer caused harm of $\$ 100$ to the plaintiff, the boycott cost the wrongdoer $\$ 25$, and the boycott benefited the wrongdoer's competitors by $\$ 25$. Thus, the net social cost equals $\$ 100$. The wrongdoer internalizes the $\$ 25$ cost of the boycott. Efficiency incentives require the wrongdoer to internalize another $\$ 75$ in social costs, which is accomplished if the court should impose damages of $\$ 75$.

${ }^{7}$ For example, if future sharp dealing caused the uncompensated harm to increase from $\$ 20$ to $\$ 25$, then ideal net damages would fall from $\$ 60$ to $\$ 55$. This result occurs because the increase in uncompensated harm increases the gain from deterrence that occurs when committing the wrong triggers the nonlegal sanction. If, however, the uncompensated harm in future cases were linked to damages in this case, then the calculation requires another term to represent this effect. Many papers
} 
As mentioned, the growing literature on social norms has not discussed the question of whether or not to deduct nonlegal sanctions from damages. The literature on antitrust law, however, discusses a problem similar to the transfer of business in example 5. An antitrust violator often transfers profits from competitors to himself. The social cost of the antitrust violation equals the harm suffered by the victim less value transferred to the violator. In general, optimal deterrence ideally requires the court to deduct from compensatory damages the value transferred to the violator. ${ }^{8}$

Now we can state the generalization underlying all five examples with the help of some notation. A wrongdoer often brings a nonlegal sanction on himself. The burden, which we denote $s_{n}$, is the cost imposed on the wrongdoer by the nonlegal sanction. (We will not discuss cases in which, instead of imposing a burden, the nonlegal sanction creates a net benefit for the wrongdoer.) $)^{9}$ In addition to the burden $s_{n}$, the nonlegal sanction may cause the transfer of value from the wrongdoer to other people, which we denote $t$. The nonlegal sanction may also create value for people other than the wrongdoer, which we denote $v$. The net social cost of the nonlegal sanction equals $s_{\mathrm{n}}-t-v$.

Each dollar in cost that the nonlegal sanction imposes on the wrongdoer creates benefits for others. Let $r$ denote this rate at which the nonlegal sanction creates benefits for people other than the wrongdoer: $r=(t+v) / s_{\mathrm{n}}$. If the nonlegal sanction is a deadweight loss, then $r=0$. If the nonlegal sanction is a pure transfer from the wrongdoer to others, then $r=1$. If the burden of the nonlegal sanction on the wrongdoer is less than the value transferred and created for others, then $r>1$. Now we can formulate a generalization.

Proposition 2. Assume that the wrongdoer causes harm $H$ to the victim, which causes the wrongdoer to suffer a nonlegal sanction $s_{\mathrm{n}}$. The nonlegal sanction creates or transfers value to people other than the wrongdoer at the rate $r$. The wrongdoer has efficient incentives to avoid causing harm when damages $D_{\mathrm{w}}$ that he pays equal $H-r s_{\mathrm{n}}$. In brief, the wrongdoer's optimal damages $D_{\mathrm{w}}^{*}$ are given by the equation

$$
D_{\mathrm{w}}^{*}=H-r s_{\mathrm{n}} .
$$

The formula $H-r s_{\mathrm{n}}$ strictly defines the ideal measure of "net damages" that we commend to theorists. The term $r$ defines the fraction or multiple of the nonlegal sanction to deduct from damages.

In practice, courts aim to award compensatory damages, so they proceed as if $r=0$. This practice would be justified if nonlegal sanctions were a

on tort law compute the adjustment in damages required when enforcement error allows some future wrongdoers to escape legal liability. See, for example, Richard Craswell, Deterrence and Damages: The Multiplier Principle and Its Alternatives, 97 Mich. L. Rev. 2185 (1999).

${ }^{8}$ William M. Landes, Optimal Sanctions for Antitrust Violations, 50 U. Chi. L. Rev. 652 (1983).

${ }^{9}$ To illustrate, the nonlegal sanction may benefit the wrongdoer when the wrongdoer's criminal subculture rewards wrongdoing. 
deadweight loss. In reality, however, nonlegal sanctions typically transfer and create value, so $r$ almost always exceeds zero and often exceeds one. When $r$ exceeds zero, proceeding as if $r=0$ distorts the incentives of wrongdoers. We will describe practical ways in which courts can correct this distortion. First, however, we show that proceeding as if $r=0$ distorts the incentives of victims as well as those of wrongdoers.

\section{VICTIMS' INCENTIVES}

Now we turn from the wrongdoers' incentives to the victims' incentives. A potential victim can often reduce the probability or magnitude of harm from a wrong. To illustrate, a promisee can help the promisor perform, rely less on the promise, or mitigate harm after breach. Similarly, a potential tort victim can reduce the activity that exposes him to risk, increase the care with which he engages in the risky activity, or search for the cheapest way to repair damage after it occurs. Finally, a property owner can locate and shield improvements to reduce their exposure to smoke, noise, or other nuisances.

Liability law typically requires wrongdoers to compensate victims. In a traditional economic analysis, however, compensating victims typically erodes their incentives to reduce the probability or magnitude of harm. Arresting the erosion of victims' incentives requires reducing damages. In traditional economic models of torts, contracts, or property, reducing damages to zero typically solves completely the victims' incentive problems, whereas other solutions solve the problem incompletely. ${ }^{10}$

Extending economic analysis to encompass social norms changes the conclusion that ideal damages for victims' incentives are zero. The wrongdoer who harms the victim by violating a social norm may provoke a nonlegal sanction that destroys, transfers, or creates value. The victim can reduce the probability or magnitude of a nonlegal sanction by reducing the probability or magnitude of the harm that triggers it. Strictly speaking, efficient incentives require the victim to internalize these effects, which can be accomplished by adjusting damages up or down, depending on whether the nonlegal sanction creates or destroys value.

To explain the ideal adjustment, we turn to an example from contract law.

Example 6. Yvonne's prosperous restaurant needs enlarging, so she contracts with Xavier to build an addition for use on September 1. To accommodate increased business in the addition, Yvonne needs to order more food than she can use in her original facility. Yvonne knows that events could prevent Xavier from completing construction on time, such as striking

\footnotetext{
${ }^{10}$ Cooter, supra note 2; Robert Cooter \& Thomas Ulen, Law and Economics 248-52 \& 302-4 (3d ed. 1999). Litigation and enforcement costs may have an influence on the optimal level of damages awarded by courts. See A. Mitchell Polinsky \& Daniel L. Rubinfeld, The Welfare Implications of Costly Litigation for the Level of Liability, 17 J. Legal Stud. 151 (1988); and Keith N. Hylton, Optimal Law Enforcement and Victim Precaution, 27 Rand J. Econ. 197 (1996).
} 
plumbers, recalcitrant city inspectors, or foul weather. Yvonne can reduce the probability of breach and the magnitude of the resulting harm in several ways. To reduce the probability of breach, Yvonne can give Xavier valuable information about the plumber's union and structural obstacles to renovating the building, and she can use her contacts in government to get the building inspection completed on time. To reduce the magnitude of the harm that breach will cause, she can restrain her food order. If breach occurs, she can mitigate damages by increasing the hours of opening the restaurant and searching for other restaurants to buy excess food.

Assume that Yvonne makes no effort to reduce the expected harm from breach, Xavier breaches, and the breach causes damages of $\$ 100$. Xavier suffers a nonlegal sanction in the form of a boycott that costs him $\$ 20$. The boycott transfers $\$ 15$ to his competitors and creates $\$ 10$ in benefits to others by deterring potential wrongdoers. What damages should the court award Yvonne?

In this section, our paper focuses on victims' incentive. Consequently, to answer this question, we focus on Yvonne's incentives and ignore Xavier's incentives. Recall that Yvonne typically has incentives to minimize social costs when she internalizes the harm affected by her actions. The harm affected by her actions includes the harm that she suffers from breach. Full compensation makes Yvonne indifferent between performance and breach, so she externalizes the benefit from cooperating with Xavier. Contractual and legal devices can ameliorate this problem, but in practice they typically stop well short of a solution. ${ }^{11}$ (In a separate paper, we will discuss achieving efficient incentives through a novel contractual device called "antiinsurance." $)^{12}$ To internalize the harm that she suffers from breach, Yvonne must not receive compensation for the harm of $\$ 100$ that she suffers.

Besides the harm that she suffers from breach, Yvonne's actions also affect the probability and magnitude of the nonlegal sanction, which costs Xavier $\$ 20$ and benefits others by $\$ 25$, for a net gain of $\$ 5$. To internalize these

\footnotetext{
"The contractual devices include stipulated damages. Cooter, supra note 2 . The legal devices include the foreseeability doctrine and the duty to mitigate damages. See Cooter \& Ulen, supra note 10 , ch. 7. A legal device available in contract in Israel but probably not in the United States is a comparative negligence defense. For comparative negligence in contracts, and for various attitudes toward it in various jurisdictions, see Ariel Porat, Contributory Negligence in Contract Law: Toward a Principled Approach, 28 U.B.C. L. Rev. 141 (1994). For comparative negligence in torts, see Robert D. Cooter \& Thomas S. Ulen, An Economic Case for Comparative Negligence, 61 N.Y.U. L. Rev. 1067 (1986). For the question of cooperation in contracts, see Restatement (Second) of Contracts $\S 205$, cmt. d (1979); J. F. Burrows, Contractual Co-operation and Implied Term, 31 Mod. L. Rev. 390 (1968); S. J. Stoljar, Prevention and Co-operation in the Law of Contract, 31 Can. B. Rev. 231 (1953); Hugh Collins, The Law of Contract 301-33 (2d ed. 1993); J. N. Adams \& Roger Brownsword, Key Issues in Contract 295-329 (1995).

${ }^{12}$ We purpose a third-party transfer contract. The first and second parties will transfer the right to collect damages in the event of breach to a third party ("the anti-insurer"), and the third party will pay the first and second parties for this right.
} 
values, Yvonne should receive damages of $\$ 5$. Yvonne's incentives are most efficient when she receives no compensation for her own losses of $\$ 100$ and she receives compensation of $\$ 5$ for the net benefit of the nonlegal sanction to others.

Proposition 3 formulates precisely the generalization underlying this example.

PRoposition 3. Assume that the wrongdoer causes harm $H$ to the victim, which causes the wrongdoer to suffer a nonlegal sanction $s_{\mathrm{n}}$. The nonlegal sanction creates or transfers value to people other than the wrongdoer at the rate $r$. By definition, the net benefit of the nonlegal sanction equals the difference between the value created or transferred to others and the cost to the wrongdoer. The victim has efficient incentives to reduce the probability and magnitude of the harm that he suffers when damages $D_{v}$ that he receives equal the net benefit of the nonlegal sanction: $D_{\mathrm{v}}^{*}=r s_{\mathrm{n}}-s_{\mathrm{n}}$.

In the absence of a nonlegal sanction $\left(s_{\mathrm{n}}=0\right)$, Proposition 3 implies the traditional conclusion that victims should receive no compensation $\left(D_{v}^{*}=\right.$ $0)$. In the presence of a nonlegal saction $\left(s_{\mathrm{n}}>0\right)$, Proposition 3 implies that the victim should ideally receive damages equal to the net value created by the nonlegal sanction $\left(r s_{\mathrm{n}}-s_{\mathrm{n}}\right)$.

Comparing Propositions 2 and 3 reveals a tension between ideal incentives for wrongdoers and victims. Proposition 2 asserts that ideal incentives for the wrongdoer require him to pay damages equal to $H-r s_{n}$, whereas Proposition 3 asserts that ideal incentives for the victim require him to receive damages equal to $r s_{\mathrm{n}}-s_{\mathrm{n}}$. Satisfying both conditions simultaneously is usually impossible. To illustrate by example 6, ideal damages for injurers' incentives equal $\$ 75$, whereas ideal damages for victims' incentives equal $\$ 5$. To avoid this trade-off and achieve the ideal for both actors simultaneously would require "decoupling," which means that the damages paid by the injurer do not equal the damages received by the victim.

In this paper we will not explore decoupling. Instead of aiming for ideal incentives, this paper makes a practical proposal. The practical proposal is to deduct the burden of the nonlegal sanction on the injurer from compensatory damages. Now we want to explain why deducting the burden improves the victim's incentives in almost every case. In almost every case, damages are ordered as follows:

compensatory $(H)>$ net practical $\left(H-s_{\mathrm{n}}\right)>$ victim's ideal $\left(r s_{\mathrm{n}}-s_{\mathrm{n}}\right)$.

Given this ordering, deducting the burden of the nonlegal sanction from compensatory damages brings damages closer to ideal damages for victims' incentives. ${ }^{13}$ To illustrate by example 6 , the victim's incentives improve by

\footnotetext{
${ }^{13}$ Note that if the value created by the nonlegal sanction exceeds net practical damages $\left(r s_{n}-\right.$ $s_{\mathrm{n}}>H-s_{\mathrm{n}}$ ), then the ideal damages for victims' incentives exceed net practical damages. In the most extreme case, the nonlegal sanction creates more value than the harm suffered by the victim
} 
deducting the sanction's burden of $\$ 20$ from compensatory damages of $\$ 100$. (Notice that if the nonlegal sanction benefited or harmed the victim, then the victim would already internalize that element of social benefit or cost, so our calculation of victims' incentives would be unaffected.)

We will summarize our conclusions about damages in example 6. Compensatory damages equal the harm Yvonne suffers from breach, or $\$ 100$. Ideal net damages for Xavier's incentives equal Yvonne's harm minus the benefit of the nonlegal sanction, or $\$ 100-\$ 25=\$ 75$. We advocate awarding practical net damages, which equal Yvonne's harm minus the burden of the nonlegal sanction on Xavier, or $\$ 100-\$ 20=\$ 80$. Besides improving Xavier's incentives, reducing damages from $\$ 100$ to $\$ 80$ would improve Yvonne's incentives. Reducing damages from $\$ 80$ to $\$ 5$ would improve Yvonne's incentives even more. ${ }^{14}$ Once damages fall below $\$ 75$, however, lowering damages to improve Yvonne's incentives worsens Xavier's incentives. (We implicitly assume that the damages paid by Xavier equal the damages received by Yvonne.) Given a trade-off, we prefer to get incentives right for injurers rather than victims.

\section{Optimizing the Nonlegal SANCTION}

The preceding analysis assumes that the court has no power to influence nonlegal sanctions. In reality, however, the court can sometimes affect nonlegal sanctions. To illustrate, in example 1 the court might increase the harm to the wrongdoer's reputation by a public condemnation in strong language. Alternatively, in example 2 , the court might increase the publicity surrounding its decision, thus increasing the scope of the boycott. In this section, we explain how the court should exercise whatever control it possesses over nonlegal sanctions in order to minimize social costs.

First, the court should substitute as far as possible a nonlegal sanction that creates or transfers value for a nonlegal sanction that destroys value. For example, boycotts mostly transfer value, whereas shaming possibly destroys more value than it transfers. Insofar as boycotts transfer value and shaming is a deadweight loss, social policy should favor boycotts rather than shaming. The court might encourage consumers to transfer business away from the wrongdoer rather than shame him. We formulate precisely the underlying generalization.

Proposition 4. Let $s_{\mathrm{n}}$ denote the nonlegal sanction and $r$ denote the rate at which it creates value. Under standard assumptions and assuming $s_{\mathrm{n}}$ is constant, the court should choose the highest possible value of $r$.

$\left(r s_{\mathrm{n}}-s_{\mathrm{n}}>H\right)$, so the victim should receive supercompensatory damages to induce the wrongdoer to harm him. This possible situation is very unlikely.

${ }^{14}$ Note that adjusting the numbers in the example could cause the ideal damages for Yvonne to fall below zero. If the net benefit of the nonlegal sanction were negative, then the ideal damages for Yvonne would be negative, which implies that she should ideally pay damages to someone else. 
Second, the court should consider whether to substitute nonlegal sanctions for damages. To illustrate, instead of awarding damages to the plaintiff, the judge might blacken the defendant's reputation. We will formulate the considerations that courts should weigh in deciding whether to substitute nonlegal sanctions for damages. To keep our comparison consistent, we consider increases in nonlegal sanctions that exactly offset decreases in damages, so the total sanction remains constant. Keeping the total sanction constant keeps the wrongdoers' incentives constant, so we can concentrate on victims' incentives.

As we have explained, reducing the damages paid to victims typically improves their incentives. Balanced against this gain is a potential loss. Whereas damages transfer value, nonlegal sanctions sometimes destroy value. To illustrate, the nonlegal sanction in example 1 is a deadweight loss. When substituting nonlegal sanctions for damages, the court must balance better incentives for victims against any losses from nonlegal sanctions. To illustrate the trade-off, lowering damages in example 1 motivates the victim to reduce the expected harm that she suffers from sexual harassment, and increasing the wrongdoer's loss of reputation increases the deadweight loss from the nonlegal sanction.

Proposition 5 formulates this trade-off.

Proposition 5. Assume the court can substitute the nonlegal sanction $s_{\mathrm{n}}$ for damages $D$, while keeping their sum constant. When substituting nonlegal sanctions for damages, minimizing costs requires the court to balance at the margin better incentives for victims against any losses from nonlegal sanctions. ${ }^{15}$ (See the Appendix for the proof.)

One implication of Proposition 5 is that whenever the nonlegal sanction causes a net benefit rather than a net cost, the court should substitute nonlegal sanctions for damages at least until damages fall to the ideal level for victims. To illustrate, the nonlegal sanction in example 6 creates net benefits of 5 , so the ideal damages for victims' incentives equal 5. According to Proposition

\footnotetext{
${ }^{15}$ We state this proposition in notation. Substituting $s_{\mathrm{n}}$ for $D$ causes the victim to change his behavior $y$ at a cost to him of wy. The change in his behavior changes the expected harm, $p H$. We write the marginal social cost of the change as

$$
\left(w_{v}+\frac{\partial p H}{\partial y}\right) \frac{\partial y}{\partial D} .
$$

The nonlegal sanction, which occurs with probability $p$, causes net social costs to increase at the rate $(1-r)$. A marginal substitution of $s_{\mathrm{n}}$ for $D$ causes an expected increase in the net social loss at the rate $p(1-r)$. The court should substitute nonlegal sanctions $s_{\mathrm{n}}$ for damages $D$ so long as the reduction in social costs caused by improved victim's behavior exceeds the expected increase in the net social costs of the nonlegal sanction,
}

$$
\left(w_{\mathrm{v}}+\frac{\partial p H}{\partial y}\right) \frac{\partial y}{\partial D} \geq p(1-r) .
$$


5 , the court should substitute nonlegal sanctions for damages until damages fall to 5 .

\section{ImPLEMENTING Net DamaGeS}

Proposition 2 formulates precisely the principle that courts should deduct the benefits transferred or created by the nonlegal sanction from damages owed to the victim by the wrongdoer. In practice, however, these benefits are difficult for courts to evaluate. We will discuss circumstances where precise valuations are unnecessary.

Circumstances sometimes arise in which immeasurable benefits from the nonlegal sanction approximately offset immeasurable harms of the victim. To illustrate, a doctor's malpractice caused a patient to suffer emotional distress (as well as pecuniary losses). Emotional distress is a social cost that the doctor should pay in principle. When people learn about the doctor's negligence, patients may boycott the doctor, and the boycott may deter malpractice by other doctors. Deterrence of others is a social benefit that courts should deduct from the doctor's liability in principle. In practice, however, emotional distress and deterrence may be immeasurable. Instead of attempting to measure these values, the court might dismiss both as offsetting and similar in magnitude.

We have discussed special circumstances in which courts do not need to value the benefits from nonlegal sanctions. In more common circumstances, courts need a valuation. The benefits of the nonlegal sanction are often relatively hard to value, whereas the burden of the nonlegal sanction on the wrongdoer is relatively easy to value. To illustrate, the benefit of deterrence in the preceding example is hard to measure, and the cost of the boycott to the doctor is relatively easy to meausre. The doctor in the preceding example might be able to document that he lost profits from a consumer boycott by comparing his earnings in the year preceding the injury to his earnings in the following year. In general, monetizing the nonlegal sanction's burden on the injurer presents courts with a problem similar to monetizing the victim's harm.

Under certain circumstances, courts can justifiably deduct the measurable burden of the nonlegal sanction on the wrongdoer rather than deduct the immeasurable benefit of the nonlegal sanction to others. ${ }^{16}$ Specifically, assume the court knows that the benefit exceeds the burden, and the court can measure the burden, but the court cannot measure the benefit. Under these assumptions, the burden is the largest deduction that the court can justify, or the "maximum justifiable deduction." In terms of our notation, if $s_{\mathrm{n}}$ is meas-

\footnotetext{
${ }^{16}$ Substituting a workable rule for an unworkable rule is not a new idea. Thus, L. L. Fuller and William Perdue argued that the rule of expectation damages in contracts is a substitute for a rule of reliance damages. L. L. Fuller \& William R. Perdue, Jr., The Reliance Interest in Contract Damages, 46 Yale L. J. 52 (1936).
} 
urable and $r$ exceeds one by an unknowable amount, then $s_{\mathrm{n}}$ is the maximum deduction justifiable by the facts known to the court.

Two facts typically establish that the benefit equals or exceeds the burden $(r \geq 1)$. First, the wrongdoer who suffers the nonlegal sanction usually competes economically or socially with others. For example, businesses compete for sales and people compete for prestige. Consequently, imposing the nonlegal sanction on the wrongdoer typically benefits competitors. Insofar as competition approximates a zero-sum game, the harm to the wrongdoer equals the benefit to competitors, so the nonlegal sanction approximates a transfer $(r=1)$.

The second fact concerns the creation, not transfer, of benefits. With most kinds of wrongs, the wrongdoer gains less than the victim loses. Preventing such a wrong causes a net social benefit. Nonlegal sanctions typically prevent future harms by deterring wrongdoers and providing potential victims with information needed to avoid being victimized. Preventing a wrong that would harm victims more than it would benefit the wrongdoer causes a net social benefit. The nonlegal sanction that prevents such wrongs creates social value $(r>1)$.

We have argued that the sum of value transferred and created typically equals or exceeds the burden of the nonlegal sanction, or $r \geq 1$. Given these facts, courts will typically reduce social costs by proceeding as if $r=1$ and deducting the nonlegal sanction rather than proceeding as if $r=0$ and not deducting the nonlegal sanction.

Note that courts can typically measure the effects of the nonlegal sanction more accurately by bifurcating the trial. The first stage determines wrongdoing and possibly triggers the nonlegal sanction. The second stage determines damages. By postponing the determination of damages until the second stage, the court gets more time to observe the consequences of the nonlegal sanction that will be deducted from compensatory damages.

Now we turn to a particular problem for courts that attempt to implement our proposal. Insofar as the victim must bring suit to trigger nonlegal sanctions, nonlegal sanctions suffer from the "victims' reporting problem." Specifically, the parties have an incentive to settle their dispute in order to avoid triggering the nonlegal sanction. ${ }^{17}$ Frequently, however, settling the dispute will not avoid triggering the nonlegal sanction. For example, nonlegal sanctions may be triggered by committing the wrong, such as not performing a

\footnotetext{
${ }^{17}$ When a suit gains little for victims (no damages), they have little incentive to sue. When a suit costs wrongdoers a lot (triggers nonlegal sanction), they have a strong incentive to settle out of court. For example, wrongdoers and victims of crimes in medieval England settled out of court in order to deprive the king of the fine that he would collect at the conclusion of a successful prosecution. See Daniel Klerman, Settlement and the Decline of Private Prosecution in Thirteenth-Century England, 19 Law \& History Rev. (forthcoming 2001). The "victims' reporting problem" requires adjusting our model in ways that we do not discuss in this paper. Like the king's fine, avoiding nonlegal sanctions motivates the settlement of suits.
} 
promise or causing an accident. ${ }^{18}$ When committing the wrong triggers the nonlegal sanction, the parties cannot avoid the nonlegal sanction by settling the dispute after the wrong was committed.

Sometimes committing a wrong results in harm, and sometimes it does not. In some cases, the wrong triggers nonlegal sanctions regardless of whether or not harm has occurred, and in other cases harm triggers the nonlegal sanctions. The preceding discussion focuses on cases in which harm or a lawsuit over the harm triggers the nonlegal sanctions. The cases in which the wrong triggers the nonlegal sanctions potentially add additional elements to the deduction from damages. If the nonlegal sanction creates a net benefit, then courts should ideally deduct the net benefit produced by the legal sanction from damages. The deduction should include the benefit caused by the nonlegal sanctions on those occasions when no one was harmed and no lawsuit occurred. In general, damages are optimal with respect to the injurer's incentives when the injurer's expected liability equals the expected harm minus the expected third-party benefits of the nonlegal sanction. To illustrate, assume the harm from an accident equals 150 and wrongdoing causes an accident in 10 percent of the cases. Also assume that each application of the nonlegal sanction causes third-party benefits of 5 , and wrongdoing always provokes a nonlegal sanction. In this example, the optimal damages should equal 100 , or $150-10 \times 5 .^{19}$

\section{SetTing the Legal Standard of Care}

Although this paper concerns damages, we will explain briefly how our argument about deducting nonlegal sanctions applies to setting the legal standard of care under a negligence rule. As with damages, the effect of the nonlegal sanction on the optimal legal standard of care depends on whether the nonlegal sanction destroys or creates value. The effect, however, works

\footnotetext{
${ }^{18}$ To illustrate, assume the promisor informs the promisee that he will not perform. In these circumstances, the promisor might offer to pay the promisee to release him from his promise. If the promisee's release would avoid the nonlegal sanction, then the victims' reporting problem exists. By settling and not reporting the injury, the promisor would suffer the nonlegal sanction from nonperformance, regardless of whether or not the promisee released him, and the victims' reporting problem disappears.

${ }^{19}$ We formulate the optimal damage rule using the same mathematical notation as in the Appendix. Assume a timeless world in which the probability that an act causes harm is independent of the probability that it provokes a nonlegal sanction. Let $p$ be the probability that the act causes harm $H, q$ be the probability that the act causes a nonlegal sanction, $s_{\mathrm{n}}$ be the burden of the nonlegal sanction on the injurer, $t$ be the transfer to third parties, $v$ be the value created for third parties, $D$ be the damages paid by injurer, and $D^{*}$ be the optimal damages. The expected net social cost is given by the formula $p H+q\left(s_{\mathrm{n}}-t-v\right)$. The injurer's expected cost is given by the formula $p D+q s_{\mathrm{n}}$. Damages are optimal when the former equals the latter: $p D^{*}+q s_{\mathrm{n}}=p H+q\left(s_{\mathrm{n}}-t-\right.$ $v$ ), which implies
}

$$
D^{*}=H-\frac{q}{p}(t+v)
$$


in the opposite direction. If the nonlegal sanction is a deadweight loss, then courts should take account of this loss when setting the legal standard of care. Specifically, a larger deadweight loss from the nonlegal sanction triggered by the wrong demands more precaution and a higher legal standard of care. Conversely, if the nonlegal sanction transfers value, the court should ignore it when setting the legal standard of care. Finally, if the nonlegal sanction creates net value, the court should take it into account in principle but not in practice. Specifically, a larger net benefit from the nonlegal sanction triggered by the wrong ideally demands less precaution and a lower legal standard of care. In practice, however, the court should typically ignore nonlegal sanctions that create value when setting the legal standard. The practical reasons for ignoring net benefits when setting the legal standard of care are the same as those for setting damages, which we already explained.

To illustrate, assume that precautions cost $\$ 100$, the expected harm to others equals $\$ 75$, and the burden of the nonlegal sanction on the injurer equals $\$ 75$. From the injurer's perspective, the nonlegal sanction represents self-risk, and the expected harm represents a risk to others. When setting the standard of care, the court should take into account self-risk as well as risk to others. ${ }^{20}$ If courts ignore the nonlegal sanction in this case, thus ignoring self-risk, it would find no liability. Whether the court should ignore the nonlegal sanction or consider it depends on whether it destroys, transfers, or creates value, as we will now explain.

When setting the legal standard, ignoring a nonlegal sanction that represents a deadweight loss is a mistake. If the burden of the nonlegal sanction in this example is a deadweight loss, then the total social harm equals $\$ 150$. Failure to take precaution costing $\$ 100$ to avoid social harm of $\$ 150$ should constitute negligence, and the wrongdoer should be liable. If the court considers the burden of the nonlegal sanction as a form of social cost, then the court will weigh social benefits and costs correctly when finding liability. Conversely, if the court ignores the nonlegal sanction's burden, it will weigh the cost of precaution of $\$ 100$ against the harm of $\$ 75$ and mistakenly conclude that failure to take precaution is not negligent. If the injurer foresees this mistake and concludes that he will not be held liable for failing to take precaution, then he will not take precaution. He will not take precaution because doing so costs him $\$ 100$ and only benefits him by avoiding selfrisk of $\$ 75$. So his decision is socially inefficient.

Now we modify the example for the case where the nonlegal sanction is a transfer, in which case the burden of $\$ 75$ on the injurer is offset by a gain of $\$ 75$ to third parties. Under this assumption, the failure to take precaution costing $\$ 100$ causes social harm costing $\$ 75$, so efficiency requires the injurer not to take precaution. If the court ignores the nonlegal sanction, it will

\footnotetext{
${ }^{20}$ See Robert Cooter \& Ariel Porat, Does Risk to Oneself Increase the Care Owed to Others? Law and Economics in Conflict, 29 J. Legal Stud. 19 (2000).
} 
conclude that the injurer was not negligent for failing to take precaution of $\$ 100$ to avoid harm of $\$ 75$, so the defendant is not liable. If the injurer is not liable, then he will not spend $\$ 100$ on precaution to avoid self-risk of $\$ 75$ caused by the nonlegal sanction. So no liability leads to efficient incentives. If, however, the court mistakenly decides that the injurer who does not take precaution is liable, then the injurer who foresees this fact will spend $\$ 100$ to avoid liability of $\$ 75$ and the nonlegal sanction of $\$ 75$. This is socially inefficient because the injurer spends $\$ 100$ to avoid social costs of $\$ 75$.

Finally, we consider the case in which the nonlegal sanction produces net social benefits. If the nonlegal sanction imposes a burden of $\$ 75$ on the injurer and creates benefits to third parties that exceed $\$ 75$, then courts should deduct the difference between these values from the expected harm to the victim when setting the standard of care. To illustrate concretely, assume that the nonlegal sanction imposes a burden of $\$ 75$ on the injurer and conveys a benefit of $\$ 85$ to third parties. By assumption, the nonlegal sanction creates a net social benefit of $\$ 10$. The difference between the victim's expected harm of $\$ 75$ and the nonlegal sanction's net social benefit of $\$ 10$ equals $\$ 65$. When setting the legal standard, the court should ideally require the injurer to take precautions costing up to $\$ 65$. In our specific example, the court ideally compares the cost of precaution of $\$ 100$ against net social costs of $\$ 65$ and finds no liability. In practice, as explained above, the court can typically ignore the nonlegal sanction's net social benefit when it sets the legal standard of care or determines damages.

Now we turn to the connection between the legal standard and damages. Under a rule of strict liability, an actor faces potential liability whenever he acts in a way that might cause harm to another. The level of damages awarded in such cases influences the expected liability of the actor. Damages above net social costs typically make the injurer overinvest in precaution. In contrast, a rule of negligence imposes potential liability whenever someone acts in a way that the court might find faulty. The standard of care applied by the court influences the expected liability of the actor, whereas increases in the level of damages above the net social costs may have relatively little influence. Specifically, increases in the level of damages have relatively little influence when the injurer feels confident that he can escape liability by satisfying the legal standard. Insofar as a rule of negligence imposes an uncertain standard of care, the incentive effects of a negligence rule resemble a rule of strict liability. Specifically, the injurer who is uncertain that he has avoided liability adjusts his precaution to the level of damages. In summary, strict liability rules make injurers' precaution relatively elastic with respect to the level of damages, whereas certain negligence rules make injurers' precaution relatively inelastic with respect to the level of damages.

This proposition has implications for our policy recommendations. We demonstrate that courts should typically deduct the burden of the nonlegal sanction from damages in order to avoid overdeterring injurers. When the 
burden is not deducted from damages, a rule of strict liability or uncertainty in a negligence rule typically aggravates the problem of overdeterrence, whereas certainty in a negligence rule ameliorates it. Even with certainty in negligence rules, deducting the burden of the nonlegal sanction from damages still has the advantage of improving incentives for the injurer's activity level.

\section{CONCLUSION}

Modern courts largely ignore the interaction between their decisions and nonlegal sanctions. Instead of ignoring nonlegal sanctions, courts should take them into account in several ways. First, deducting nonlegal sanctions typically reduces social costs by improving the incentives of wrongdoers and victims. In many cases, the deduction would significantly reduce damages, especially in close-knit communities and cyberspace where nonlegal sanctions work. The precise extent of the typical deduction is unknown because so little research measures nonlegal sanctions. ${ }^{21}$

Second, courts should substitute nonlegal sanctions for legal sanctions such as damages. Substitution of equivalents improves the incentives of victims and does not change the incentives of wrongdoers. Courts can improve the targeting of nonlegal sanctions by replacing rumors with authoritative determinations of facts. (Changes in court practices could further increase the information provided to citizens.) $)^{22}$ The imprecision of nonlegal sanctions represents a practical obstacle to their invocation by courts. Perhaps courts can increase the precision of their influence on nonlegal sanctions by better calibrating the language for condemning wrongdoing. ${ }^{23}$

By reducing damages, our proposal undermines the legal goal of compensating victims. We live in an age of extensive private and public insurance. Many reformers believe that insurance provides more reliable and efficient compensation of victims than liability. ${ }^{24}$ Like these reformers, we believe that the goal of compensation should diminish in importance for law as

\footnotetext{
${ }^{21}$ We know of no empirical research that measures the benefit to other people from harming the reputation of wrongdoers. We know of little empirical research measuring the cost of harm to reputation. See John R. Lott, Jr., An Attempt at Measuring the Total Monetary Penalty from Drug Convictions: The Importance of an Individual's Reputation, 21 J. Legal Stud. 159 (1992); Jonathon M. Karpoff \& John R. Lott, Jr., The Reputational Penalty Firms Bear for Committing Criminal Fraud, 36 J. Law \& Econ. 757 (1993).

${ }^{22}$ For example, instead of finding "liable" or "not liable," courts would find "liability proved," "liability disproved," or "liability unproved." This is a civil version of the criminal judgments used by Scottish courts: "guilty," "innocent," or "unproved."

${ }^{23}$ For relevant empirical research, see Cass R. Sunstein, Daniel Kahneman \& David Schkade, Assessing Punitive Damages (with Notes on Cognition and Valuation in Law), 107 Yale L. J. 2071 (1998).

${ }^{24}$ Thus, Steven Sugarman advocates replacing tort liability with social insurance. Steven D. Sugarman, Doing away with Tort Law, 73 Cal. L. Rev. 555 (1985); Steven D. Sugarman, Doing away with Personal Injury Law: New Compensation Mechanisms for Victims, Consumers, and Business (1989).
} 
insurance expands. More complete insurance markets free liability law from the need to compensate victims, so liability law can minimize social costs by various means, including deducting nonlegal sanctions from damages.

\section{MATHEMATICAL APPENDIX}

We adopt and extend the notation from John Prather Brown as used by Robert Cooter and Thomas Ulen: $:^{25}$

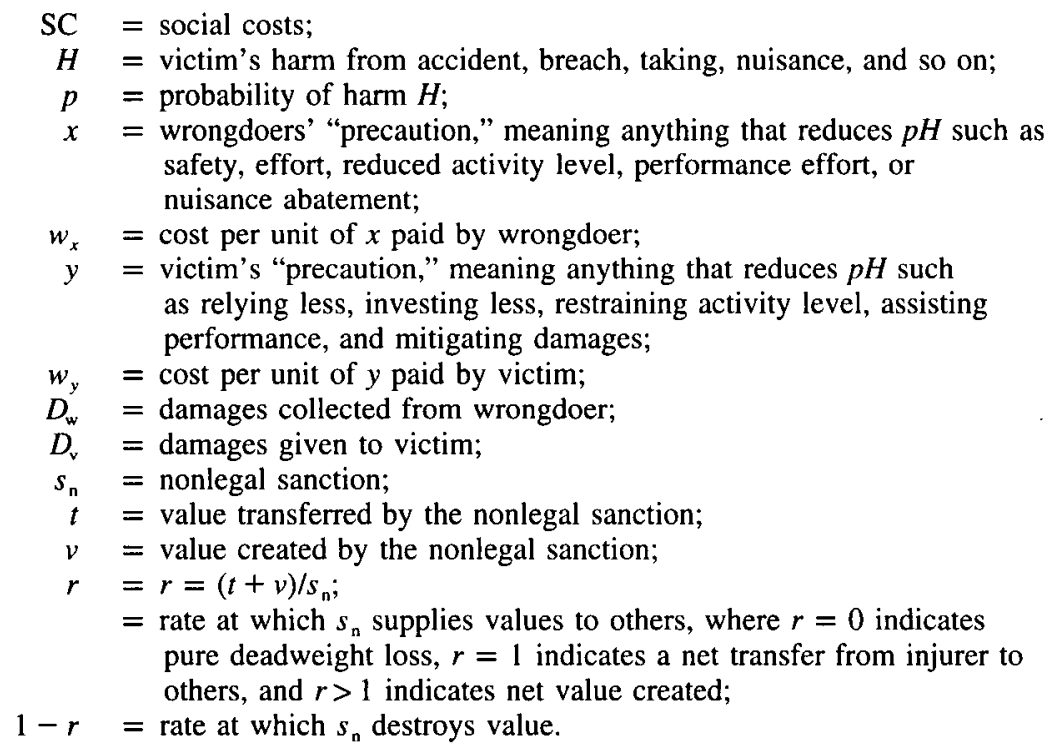

We assume the following continuous, concave functions:

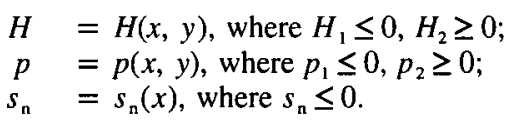

Social costs are defined by

$$
\mathrm{SC}=w_{x} x+w_{y} y+p(x, y)\left[H(x, y)+(1-r) s_{\mathrm{n}}\right] .
$$

The wrongdoer solves

$$
\min _{x \geq 0} w_{x} x+p(x, y)\left[D_{\mathrm{w}}+s_{\mathrm{n}}\right] .
$$

We denote the solution by the function

$$
\tilde{x}=x\left(w_{x}, D_{\mathrm{w}}+s_{\mathrm{n}}, y\right) .
$$

The victim solves

\footnotetext{
${ }^{25}$ John Prather Brown, Toward a Mathematical Theory of Liability, 2 J. Legal Stud. 323 (1973); Cooter \& Ulen, supra note 10.
} 


$$
\min _{y \geq 0} w_{y} y+p(x, y)\left[H(x, y)-D_{\mathrm{v}}\right] .
$$

We denote the solution by the function

$$
\tilde{y}=y\left(w_{y}, D_{v}, x\right) .
$$

Assume $D_{\mathrm{v}}=D_{\mathrm{w}}=D$.

Solve (A3) and (A5) simultaneously and substitute the result into (A1) to obtain

$$
\mathrm{SC}=\mathrm{SC}\left(w_{x}, w_{y}, D, s_{\mathrm{n}}\right) .
$$

Now we prove the propositions in the paper.

Proposition 1. Assume that $r=0$. If $D_{\mathrm{w}}=H$, then the wrongdoer has efficient incentives.

Proof. Set $r$ equal to 0 and repeat the proof of Proposition 2 below.

Proposition 2. If $D_{w}=H-r s_{n}$, then the wrongdoer has efficient incentives.

Proof. Substitute $H-r s_{\mathrm{n}}$ for $D_{\mathrm{w}}$ in (A2) and observe that the derivatives of (A1) and (A2) with respect to $x$ are identical.

Proposition 3. If $D=-(1-r) s_{\mathrm{n}}$, then the injurer has efficient incentives.

Proof. Substitute $-(1-r) s_{\mathrm{n}}$ for $D_{\mathrm{v}}$ in (A4) and observe that the derivatives of (A4) and (A1) with respect to $y$ are identical.

Proposition 4. If the court can choose $r$, it should choose the highest possible value of $r$.

Proof. By (A1), SC is decreasing in $r$.

Proposition 5. Assume $D=D_{v}=D_{w}$. Assume the court can substitute the nonlegal sanction $s_{\mathrm{n}}$ for damages $D$ while keeping their sum constant. The court should substitute nonlegal sanctions $s_{\mathrm{n}}$ for damages $D$ so long as

$$
p(1-r) \leq\left(w_{y}-\frac{\partial p H}{\partial y}\right) \frac{\partial y}{\partial D} .
$$

Proof. When we substitute $s_{\mathrm{n}}$ for $D, x$ does not change by (A3).

Holding $x$ constant in (A1), take the differential,

$$
\delta \mathrm{SC}=p(1-r) \delta s_{\mathrm{n}}+\frac{\partial \mathrm{SC}}{\partial y} \frac{\partial y}{\partial D} \delta D .
$$

Expand the partial derivates and use the fact that $\delta s_{\mathrm{n}}=-\delta D$,

$$
\delta \mathrm{SC}=p(1-r) \delta s_{\mathrm{n}}-\left(w_{y}+\frac{\partial p H}{\partial y}\right) \frac{\partial y}{\partial D} \delta s_{\mathrm{n}} .
$$

If this change weakly reduces social costs, then $\delta \mathrm{SC} \leq 0$. Hence

$$
p(1-r) \leq\left(w_{y}+\frac{\partial p H}{\partial y}\right) \frac{\partial y}{\partial D} .
$$

